\title{
Soil Chemical Amendments and the Macronutrients Mobility Evaluation in Oxisol Treated With Biochar
}

\author{
Josely Dantas Fernandes ${ }^{1}$, Lúcia Helena Garófalo Chaves ${ }^{1}$, Jacqueline da Silva Mendes ${ }^{1}$, Iêde de Brito Chaves ${ }^{1}$ \\ $\&$ Gilvanise Alves Tito ${ }^{1}$ \\ ${ }^{1}$ Department of Agricultural Engineering, Federal University of Campina Grande, Campina Grande, Paraiba, \\ Brazil \\ Correspondence: Lúcia Helena Garófalo Chaves, Department of Agricultural Engineering, Federal University of \\ Campina Grande, Avenue Aprigio Veloso, 882, Campina Grande, CEP 58429-140, Paraiba, Brazil. Tel: \\ 55-83-2101-1186. E-mail: lhgarofalo@hotmail.com
}

$\begin{array}{lcc}\text { Received: June 7, } 2018 & \text { Accepted: July 9, } 2018 \quad \text { Online Published: September 15, } 2018 \\ \text { doi:10.5539/jas.v10n10p238 } & \text { URL: https://doi.org/10.5539/jas.v10n10p238 }\end{array}$

\begin{abstract}
Biochar is material produced during a process called pyrolysis. This material can be used as fertilizer to increase the agronomic productivity of low fertility soils. The objective of this study was to evaluate the soil chemical amendments and the macronutrients leaching following biochar application, produced from poultry litter, in Yellow Red Latosol in laboratory experiments. Soil columns (height $20 \mathrm{~cm}$ ) containing 0; 10; 15;20;25 and $30 \mathrm{t}$ $\mathrm{ha}^{-1}$ of biochar with four replications totaled 24 experimental units. For 30 days, water was applied daily to each column, and the leachates were collected and chemically characterized. After this period, soil samples were taken from the 0-10 and 10-20 cm layer depth and chemically characterized. Biochar reduced exchangeable acidity values. Biochar improved soil fertility. Leachates contained increasing EC, $\mathrm{K}, \mathrm{Na}, \mathrm{Ca}$ and $\mathrm{Mg}$, however the concentration of these elements were small in relation to the biochar doses.
\end{abstract}

Keywords: poultry litter, soil chemical attributes, nutrient leaching

\section{Introduction}

Brazil, the world's largest chicken exporter, is the third largest producer country behind only the United States and China USDA (2010). This poultry activity leads to an expressive production of poultry litter, an organic residue that can be a valuable input due to the high concentration of nutrients. The use of this residue promotes a great improvement in fertility, besides being an exceptional soil conditioner, improving its physical, chemical and biological characteristics (Mueller et al., 2013). However, due to the risk of environmental contamination by numerous mechanisms of release of nutrients from the poultry litter, mainly nitrogen, to the soil and, consequently, to groundwater, it has been discussed with regard to the use of the poultry litter to the ground, that is , regarding the proper management of this residue (Oviedo-Rondon, 2008).

The transformation and recycling of the poultry litter through the pyrolysis process at a maximum temperature of $700{ }^{\circ} \mathrm{C}$ and with low or zero $\mathrm{O}_{2}$ concentration produces a co-product called biochar (mainly $\mathrm{C}, \mathrm{O}, \mathrm{H}, \mathrm{N}$ and ash), as well as gas by (mainly hydrogen, methane and carbon monoxide) and bio-oil (alcohols, oils, tar and acids) (Laird et al., 2010; Novak et al., 2009).

When applied to the soil as a conditioner and/or fertilizer, the poultry litter biochar increased the cation exchange capacity of a Yellow Red Latosol (Andrade et al., 2015), released phosphorus into the Ultisol, Oxisol and Entisol (Mendes et al., 2015a), improved the chemical properties of Ultisol, Oxisol and Entisol, increased soil pH reflecting the fact that the liming potential increased with increasing application rates of biochar (Mendes et al., 2015b), increased the adsorption of $\mathrm{Zn}$ in Ultisol and Entisol in the samples with pH 4 (Lima et al., 2017), improved the physical properties of Ultisol (Chaves et al., 2018) and promoted an increase in sunflower growth rates in the evaluation periods (Furtado \& Chaves, 2018). However, there is little information about vertical and descending movement of the chemical elements by the profile of bio-carbon applied to agricultural soils. In this context, the objective of this study was to evaluate the soil chemical amendments and the macronutrients leaching following biochar application in Yellow Red Latosol in laboratory experiments. 


\section{Materials and Methods}

\subsection{Design and Treatments}

The experiment was carried out in Irrigation and Salinity Laboratory of the Agricultural Engineering Department, UFCG, from May 2017 to July 2017 using leach columns described in section 2.4. The design was completely randomized, in subdivided plots, with 4 replications. The plots corresponded to the six biochar doses $(0 ; 7.85$; $11.77 ; 15.7 ; 19.62$ and $23.55 \mathrm{~g} / 0.00785 \mathrm{~m}^{2}$, according to $0,10,15,20,25$ and $30 \mathrm{th}^{-1}$ ) and the subplots were the soil depths $(0-10$ and $10-20 \mathrm{~cm})$.

\subsection{Biochar Analysis}

The biochar used in this study was produced from poultry litter (PL), a solid waste resulting from chicken rearing, under slow pyrolysis, at a temperature of $400{ }^{\circ} \mathrm{C}$, by SPPT Technological Research Ltda. The following attributes were found according to the methodology Brasil (2014): $\mathrm{pH}=9.45, \mathrm{P}_{2} \mathrm{O}_{5}=7.78 \%, \mathrm{~K}_{2} \mathrm{O}=4.90 \%, \mathrm{Ca}=$ $6.83 \%, \mathrm{Mg}=1.34 \%, \mathrm{Na}=0.73 \%, \mathrm{~S}=0.74 \%, \mathrm{Fe}=0.46 \%, \mathrm{Mn}=0.09 \%, \mathrm{Cu}=0.04 \%, \mathrm{Zn}=0.08 \%, \mathrm{~B}=0.01 \%$, organic matter $=39.77 \%$.

\subsection{Soil Analysis}

Soil sample used was collected from the top layer $(0-0.20 \mathrm{~m})$ of a Yellow Red Latosol, located in the municipality Areia, State of Paraiba, Brazil. This sample was, then, air-dried for 3 days, sieved with $2 \mathrm{~mm}$ screen and characterized according to the methodology EMBRAPA (2011) presenting the following physical and chemical attributes: clay $=305.5 \mathrm{~g} \mathrm{~kg}^{-1}$, silt $=262.0 \mathrm{~g} \mathrm{~kg}^{-1}$, sand $=432.5 \mathrm{~g} \mathrm{~kg}^{-1}, \mathrm{pH}\left(\mathrm{H}_{2} \mathrm{O}\right)=5.30, \mathrm{Ca}=0.93$ $\mathrm{cmol}_{\mathrm{c}} \mathrm{kg}^{-1}, \mathrm{Mg}=0.55 \mathrm{cmol}_{\mathrm{c}} \mathrm{kg}^{-1}, \mathrm{Na}=0.02 \mathrm{cmol}_{\mathrm{c}} \mathrm{kg}^{-1}, \mathrm{~K}=0.04 \mathrm{cmol}_{\mathrm{c}} \mathrm{kg}^{-1}, \mathrm{H}=1.83 \mathrm{cmol}_{\mathrm{c}} \mathrm{kg}^{-1}, \mathrm{Al}=1.8 \mathrm{cmol}_{\mathrm{c}}$ $\mathrm{kg}^{-1}, \mathrm{P}=3.3 \mathrm{mg} \mathrm{kg}^{-1}$, organic matter $=13.6 \mathrm{~g} \mathrm{~kg}^{-1}$.

\subsection{Leaching Columns}

Soil column was prepared using PVC pipe with diameter of $10 \mathrm{~cm}$ and length of $22 \mathrm{~cm}$. In general it is in the first $22 \mathrm{~cm}$ of the soil that the chemical reactions between the soil and any corrective occurs, and the presence of greater density of the roots. Soil sample was put into the column and compacted by knocking the base of the column until the soil height achieved $20 \mathrm{~cm}$; the treatments biochar was incorporated into the top $5 \mathrm{~cm}$ of the soil in the columns in order to simulate the disposition of this material on the surface as usually organic matter is applied to the soil. In the other $2 \mathrm{~cm}$ of the upper part were not filled with soil in order to facilitate the addition of water during the percolations. The lower part of the columns was sealed with a mesh to retain the soil in the columns and facilitate the drainage of the leachate which was collected in containers placed below them. The column was placed in trays containing water to reach the field capacity through the capillary ascension. After 24 $\mathrm{h}$, on each column, a volume of $40.0 \mathrm{~mL}$ of deionized water was applied daily, simulating a monthly rainfall of $168.15 \mathrm{~mm}$ (average for the city of Campina Grande in April).

The leached solution was collected daily during the experimental period ( 30 days) and conditioned in $1000 \mathrm{~mL}$ reservoirs, for complete chemical analysis (APHA, 2012). After this period, each column was sectioned in two parts, $10 \mathrm{~cm}$ each $(0-10 \mathrm{~cm}$, denominated "top", 10-20 cm, denominated "base") dried at room temperature, homogenized and sampled for chemical analysis (EMBRAPA, 2011).

\subsection{Statistical Analysis}

The data of the leachate and the soil were submitted to analysis of variance (ANOVA) applying the SISVAR software (Ferreira, 2011). With the significance of the doses the average of the parameters evaluated in the soil (plots) and in the leachate were submitted to regression analysis. These parameters were also analyzed in the soil according to the two depths (subplots) comparing their means to each other within the same dose by the "t" test.

\section{Results and Discussion}

Biochar doses, soil depths, and interaction of these sources of variation significantly influenced soil chemical parameters (Table 1). 
Table 1. Summary of variance analysis related to $\mathrm{pH}$, electric conductivity (EC), calcium (Ca), magnesium (Mg), phosphorus $(\mathrm{P})$, sodium $(\mathrm{Na})$, potassium $(\mathrm{K})$, carbon $(\mathrm{C})$, potential acidity $(\mathrm{H}+\mathrm{Al})$ and cation exchange capacity (CEC) in the two soil layers as a function of the applied biochar doses

\begin{tabular}{|c|c|c|c|c|c|c|c|c|c|c|c|}
\hline \multirow{2}{*}{ Source of variation } & \multirow{2}{*}{$\mathrm{DF}$} & \multicolumn{10}{|c|}{ F-test } \\
\hline & & $\mathrm{pH}$ & $\mathrm{EC}$ & $\mathrm{Ca}$ & $\mathrm{Mg}$ & $P$ & $\mathrm{Na}$ & $\mathrm{K}$ & $\mathrm{C}$ & $\mathrm{H}+\mathrm{Al}^{(1)}$ & CEC \\
\hline Doses (D) & 5 & $2.23^{* *}$ & $0.107^{* *}$ & $0.199^{* *}$ & $0.37^{* *}$ & $4670.6^{* *}$ & $0.11^{* *}$ & $2.50^{* *}$ & $4.79^{*}$ & $0.269^{* *}$ & $4.05^{* *}$ \\
\hline residue 1 & 15 & 0.008 & 0.001 & 0.007 & 0.009 & 38.49 & $1 e^{-4}$ & 0.02 & 1.28 & $3 e^{-3}$ & 0.09 \\
\hline Depth (De) & 1 & $26.06^{* *}$ & $0.053^{* *}$ & $4.29^{* *}$ & $6.45^{* *}$ & $67594.5^{* *}$ & $0.092^{* *}$ & $7.72^{* *}$ & $120.6^{* *}$ & $17.16^{* *}$ & $15.89^{*}$ \\
\hline $\mathrm{D} \times \mathrm{De}$ & 5 & $1.55^{* *}$ & $0.003^{*}$ & $0.65^{* *}$ & $1.10^{* *}$ & $4606.38^{* *}$ & $0.015^{* *}$ & $0.52^{* *}$ & $16.91^{* *}$ & $0.264^{* *}$ & $3.66^{* *}$ \\
\hline \multicolumn{12}{|l|}{$\mathrm{D} / \mathrm{Del}$} \\
\hline Linear & 1 & $16.81^{* *}$ & $0.277^{* *}$ & $403.2^{* *}$ & $6.03^{* *}$ & $45321.3^{* *}$ & $0.508^{* *}$ & $12.87^{* *}$ & $87.13^{* *}$ & $1.44^{* *}$ & $34.83^{* *}$ \\
\hline Quadratic & 1 & $1.89^{* *}$ & $0.007^{*}$ & $20.5^{* *}$ & $0.14^{*}$ & $287.57^{*}$ & $6 \mathrm{e}^{-4 n s}$ & $0.17^{* *}$ & $0.27^{\mathrm{ns}}$ & $0.90^{* *}$ & $0.95^{*}$ \\
\hline Deviation & 3 & $0.02^{\text {ns }}$ & $0.003^{*}$ & $1.6^{\mathrm{ns}}$ & $0.07^{*}$ & $258.25^{* *}$ & $4 e^{-4 n s}$ & $0.07^{*}$ & $1.07^{\mathrm{ns}}$ & $0.06^{* *}$ & $0.31^{\text {ns }}$ \\
\hline \multicolumn{12}{|l|}{$\mathrm{D} / \mathrm{De} 2$} \\
\hline Linear & 1 & $34.11^{* *}$ & $0.25^{* *}$ & $0.26^{* *}$ & $0.44^{* *}$ & $3.07^{\mathrm{ns}}$ & $0.112^{* *}$ & $1.822^{* *}$ & $13.03^{* *}$ & $0.01^{\mathrm{ns}}$ & $7 e^{-4 n s}$ \\
\hline Quadratic & 1 & $0.60^{\mathrm{ns}}$ & $1 \mathrm{e}^{-4 \mathrm{~ns}}$ & $0.15^{* *}$ & $0.50^{* *}$ & $3.02^{\mathrm{ns}}$ & $2 e^{-3 n s}$ & $0.020^{\mathrm{ns}}$ & $0.04^{\mathrm{ns}}$ & $0.01^{\mathrm{ns}}$ & $0.11^{\mathrm{ns}}$ \\
\hline Deviation & 3 & $3.73^{*}$ & $1.3 \mathrm{e}^{-3 \mathrm{~ns}}$ & $5 e^{-3 n s}$ & $9 \mathrm{e}^{-3 \mathrm{~ns}}$ & $3.23^{\mathrm{ns}}$ & $4 e^{-5 n s}$ & $8 \mathrm{e}^{-3 \mathrm{~ns}}$ & $1.61^{\mathrm{ns}}$ & $0.03^{*}$ & $0.57^{*}$ \\
\hline residue 2 & 21 & 0.00 & 0.001 & 0.008 & 0.021 & 45.57 & $4 e^{-4 n s}$ & 0.02 & 1.40 & 0.004 & 0.15 \\
\hline CV $1(\%)$ & & 1.35 & 1.35 & 12.72 & 7.34 & 9.31 & 15.21 & 4.01 & 18.00 & 19.05 & 4.14 \\
\hline CV $2(\%)$ & & 1.02 & 1.02 & 11.31 & 7.93 & 14.20 & 16.55 & 8.02 & 15.42 & 19.88 & 4.81 \\
\hline General Average & & 6.70 & 6.70 & 0.29 & 1.19 & 1.04 & 40.79 & 0.27 & 0.93 & 5.96 & 1.45 \\
\hline
\end{tabular}

Note. Significant at $5 \%(*)$ and $1 \%(* *)$ of probability by F test, ns= not significant, DF = Degree of freedom, $\mathrm{CV} \%=$ Coefficient of variation, ${ }^{(1)}$ Data transformed to $\sqrt{x+0.5}$.

As shown in Figure 1A, pH practically did not vary in the soil without biochar, however, the biochar applied to the soil increased soil $\mathrm{pH}$ in the two layers analyzed (top and base), corroborating Yuan and Xu (2012), and Silva et al. (2017) who observed an increase in $\mathrm{pH}$ of the soil, considering the positive effect of biochar, particularly in acid soils. However, more significant changes were observed at the top whose calculated maximum $\mathrm{pH}$ value reached 8.22 applying $29.28 \mathrm{tha}^{-1}$ (Figure 1A).

At the base of the column the $\mathrm{pH}$ averages were adjusted to the linear model, presenting an increase of 0.0081 units to each ton of biochar/hectare, i.e., these values $\mathrm{pH}$ remained relatively unchanged regardless of the doses applied. This result shows that soil acidity neutralization reactions occur in the biochar incorporation layer. In relation to this chemical attribute, the statistically significant mean $\mathrm{pH}$ in the top soil was higher than that observed in the base soil, regardless of the biochar levels applied (Figure 1A). 


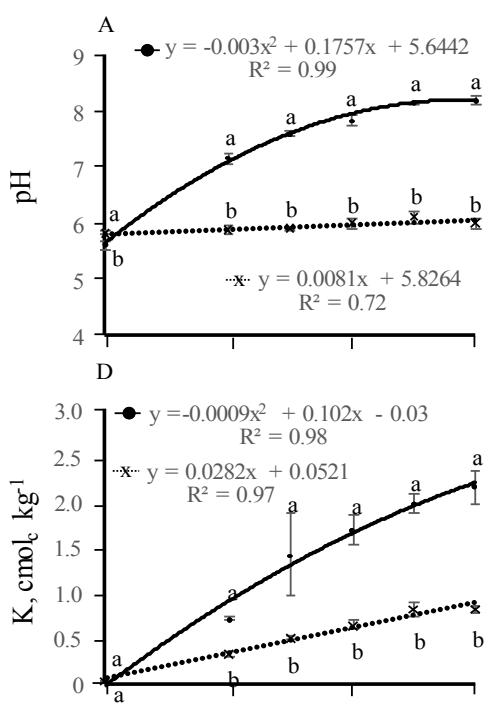

G
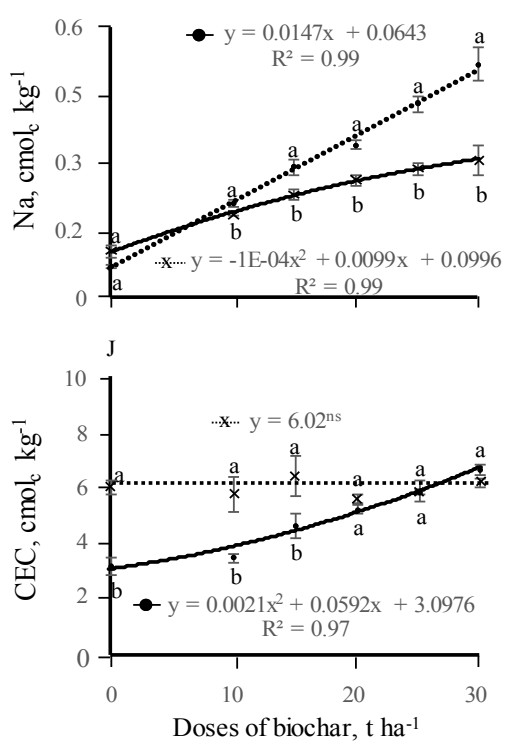
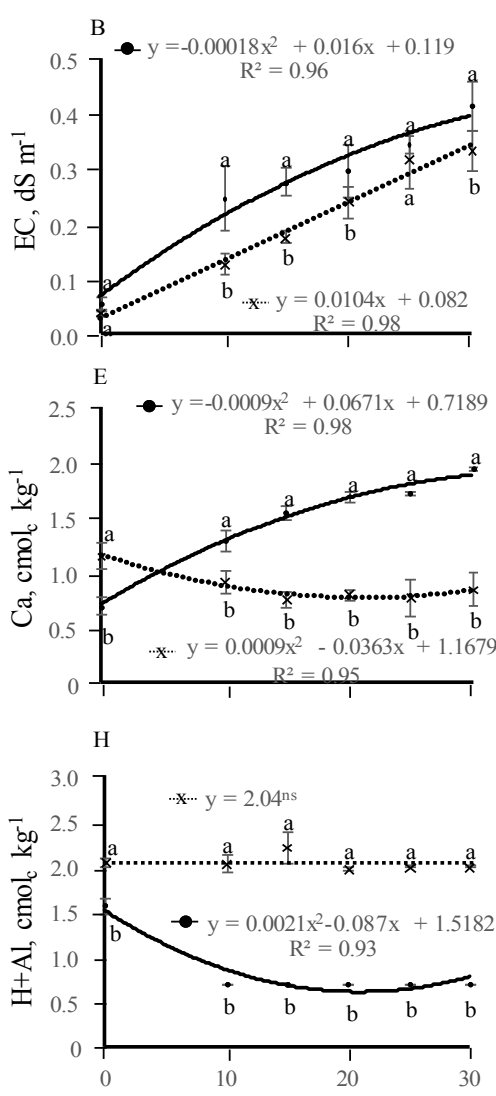

Doses of biochar, $\mathrm{tha}^{-1}$
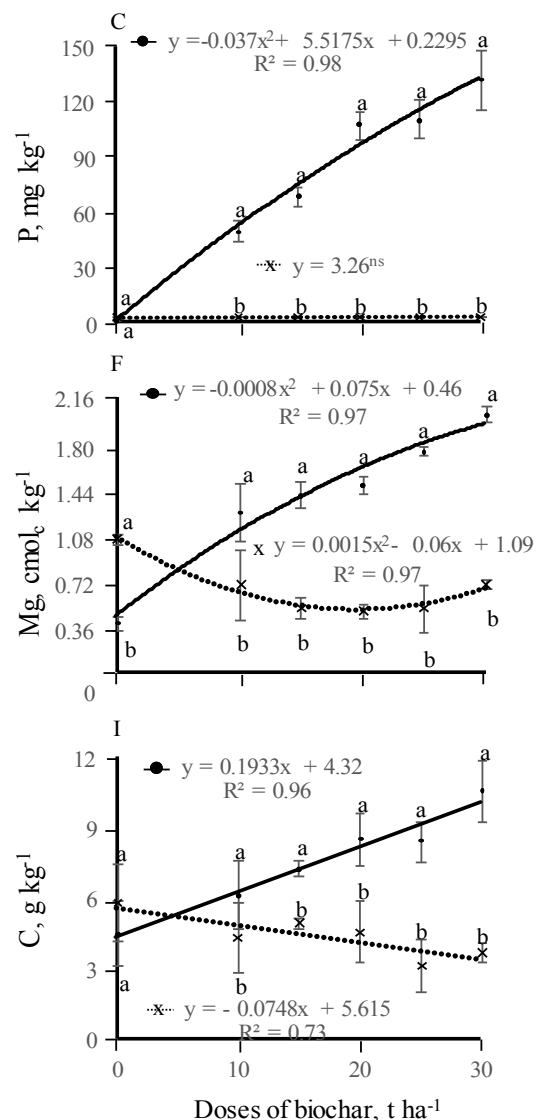

Doses of biochar, $\mathrm{t} \mathrm{ha}^{-1}$

Depth $0-10 \mathrm{~cm}$

.X. Depth 10-20cm

Figure 1. Behavior of the chemical parameters at the top and base of the soil column as a function of increasing doses of biochar. Vertical bars represent the standard error and averages followed by the same lowercase letter do not differ statistically between depths within the same dose of biochar

According to Sparks (2003), changes in soil $\mathrm{pH}$ occur when cations from the biochar displace the aluminum (Al) from the clay exchange sites and/or organic matter and then react with soluble monomeric Al species. Moreover, depending on the biomass to be used in the preparation of the biochar, basic cations such as $\mathrm{Ca}, \mathrm{K}, \mathrm{Mg}$ and $\mathrm{Si}$ may form alkali oxides or carbonates during the pyrolysis process and, once released into the environment, react with $\mathrm{H}^{+}$and monomeric $\mathrm{Al}$, increasing the $\mathrm{pH}$ of the soil and decreasing the exchangeable acidity (Novak et al., 2009). In a study by Van Zwieten et al. (2010) was shown that carbonates from biochar promoted a higher growth of wheat, overcoming the toxic effects of acid soils.

The electrical conductivity presented a behavior similar to the $\mathrm{pH}$ of the soil, whose averages increased as a function of the application of increasing doses of biochar. The mean electric conductivity (EC) values of the top soil were adjusted to the second order polynomial regression model, whose observed maximum value corresponded to $0.48 \mathrm{dS} \mathrm{m}^{-1}$ with the application of an overestimated dose in $44 \mathrm{tha}^{-1}$. At the base, the highest EC $\left(0.39 \mathrm{dS} \mathrm{m}^{-1}\right)$ was verified by applying $30 \mathrm{tha}^{-1}$ of biochar. Comparing the EC values between the two depths analyzed it can be seen that only in the absence and the dose of $25 \mathrm{t} \mathrm{ha}^{-1}$ of biochar their means do not differ from each other (Figure 1B). 
The increase of the electrical conductivity in the soil samples is related to the increase of the exchangeable bases (potassium, calcium, magnesium and sodium) available from the biochar. At the top there was a significant increase of these bases, however, in the base, only the potassium and sodium contents (Figures 1D and 1G) increased as a function of the doses of biochar. Moreover, the increase in the negative electric charges of the soil, promoted by the elevation of the $\mathrm{pH}$, contributed to a decrease in the mobility of such elements.

It is evident that the increase in EC values due to the application of biochar in the soil will depend on the source material of the biochar. For example, Silva et al. (2017) using rice, sawdust and sorghum silage biochar observed values of electrical conductivity of $121.8,69.8$ and $97 \mathrm{mS} \mathrm{cm}^{-1}$, respectively.

The phosphorus in the soil of the upper layer of the column was influenced by the addition of the biochar, presenting a maximum concentration of $205.92 \mathrm{mg}$ applying $74.56 \mathrm{t} \mathrm{ha}^{-1}$ of biochar. This behavior was not observed when the soil was analyzed in the base, that is, the phosphorus levels did not differ statistically between the doses, presenting a mean concentration of $3.26 \mathrm{mg} \mathrm{dm}^{-3}$, practically equal to that of the control. The phosphorus content analyzed differed between the depths with the exception of the absence of biochar (Figure 1C). This is due to the fixation of the phosphorus to the soil, not leaching of this element along the column.

In weathered soils with predominance of iron and aluminum hydroxides, there is a tendency of the phosphorus to be retained in these structures and, therefore, little available in the soils. One way of minimizing such a problem is to raise soil $\mathrm{pH}$, as this phenomenon increases hydroxyl $(\mathrm{OH})$ dissociation at the ends and surfaces of the mineral or organic matter particles, resulting in an increase in the net negative charge thereof, reduction of phosphorus adsorption reactions, making it more available in soil solution.

The high concentration of $\mathrm{P}$ in the biomass used in this research (7.78\%) and the increase in soil $\mathrm{pH}$ promoted by this residue, mainly at the top, positively influenced the increase of soil P corroborating Martinez et al. (2017). According to these authors, after eight consecutive desorption, the biochar of Eucalyptus globulus increased the release of phosphorus in comparison with the natural soil, between 78 and $84 \%$, thus promoting a greater availability of this element over the time necessary for the correct nutrition of the plants.

The application of biochar significantly influenced the potassium content, presenting at the top a maximum concentration of $2.87 \mathrm{cmol}_{\mathrm{c}} \mathrm{dm}^{-3}$ with an overestimated dose of $56.77 \mathrm{t} \mathrm{ha}^{-1}$. The content of this element in the soil at the base of the column increased at a rate of $0.03 \mathrm{cmol}_{\mathrm{c}} \mathrm{dm}^{-3}$ to each ton of biochar applied (Figure $1 \mathrm{D}$ ). The sodium content increased proportionally with the application of the biochar, in order to present a concentration of 0.34 and $0.50 \mathrm{cmol}_{\mathrm{c}} \mathrm{dm}^{-3}$ at the top and base of the soil column, respectively, at the 49.5 and 30 $t \mathrm{tha}^{-1}$ dosages (Figure 1G). By evaluating the effect of depth within each biochar level, it is verified that there was a significant difference, both in relation to potassium (Figure 1D) and sodium (Figure 1G), except in the absence of biochar.

Calcium and magnesium, in the absence of biochar, presented higher levels at the base of the soil column, however, when biochar was applied, a decrease in the mobility of these nutrients was observed, with higher levels at the top of the column. Laird et al. (2010) in their research verified significant reductions in leachate contents of calcium, magnesium, silicon, nitrogen and potassium proportionally to the applied rates of biochar. The mean calcium and magnesium contents at the top of the column were adjusted to the second order polynomial regression model whose maximum values corresponded to 1.97 and $2.23 \mathrm{cmol}_{\mathrm{c}} \mathrm{dm}^{-3}$, applying 37.27 and $47.13 \mathrm{tha}^{-1}$, respectively (Figures $1 \mathrm{E}$ and $1 \mathrm{~F}$ ). The contents of these elements differed between the depths independently of the applied biochar levels.

The results obtained in this research corroborate Major et al. (2010), who also verified an increase in $\mathrm{pH}$, availability of phosphorus and exchangeable cations, such as $\mathrm{Ca}, \mathrm{Mg}, \mathrm{Na}$ and $\mathrm{K}$ in the soil.

In spite of having decreased the contents of the elements analyzed at the base of the column, there was a mobility of them according to the following sequence: $\mathrm{Na}>\mathrm{K}>\mathrm{Mg}>\mathrm{Ca}>\mathrm{P}$ whose percentage values in relation to the quantities of each element applied with the dose of $30 \mathrm{t} \mathrm{ha}^{-1}$ of biochar corresponded to $41.22 \%$; $30.43 \%$; $25.52 \% ; 11.11 \%$ and $0.18 \%$, respectively. $\mathrm{Na}$ and $\mathrm{K}$ competed with $\mathrm{Ca}$ for the exchange sites at the soil surface because they are monovalent cations and had a concentration of 9.4 and 1.4 times lower in relation to $\mathrm{Ca}$, respectively, which caused higher vertical flow in the leaching column.

It is important to emphasize that the soil used in this research is a Red Yellow Latosol, presenting as characteristics a high degree of weathering, intense leaching, clays with low activity and low values of cation exchange capacity (CEC) and $\mathrm{pH}$ (EMBRAPA, 2013).

The increase in this soil fertility due to the application of biochar in the soil will depend on the source material of the biochar. For example, the biochar used in this research was made from chicken litter, whose base of bird feed 
is: corn, soybean, limestone, dicalcium phosphate and nucleus (mineral vitamin supplement amino acid); the concentration of nutrients and the amount of feed offered vary according to the category of the chicken (cutting or laying) and the nutritional requirement of the animal at different stages of development. The nutrients provided by biochar are derived from the substrate used in poultry such as "bed" and poultry feces, and the bed may have an increase in nutritional composition when it is reused in new chicken lots (Mendes et al., 2012).

According to Patterson et al. (1998), for every $100 \mathrm{~kg}$ of feed consumed by broiler chickens in commercial lots in the United States, 30.56, 57.40 and $80.04 \%$ of N, P and K consumed, respectively, will be present in the bed. This bed after the pyrolysis process, with the exception of nitrogen, will present an increase in nutrient concentration, such as phosphorus, which is only volatilized at pyrolysis temperatures above $760{ }^{\circ} \mathrm{C}$ (Knicker, 2007).

As expected, the application of biochar to the soil showed an increase in the organic carbon concentration at the top of the column, with a significant difference in the content between the depths with the exception of the absence of biochar (Figure 1I). At the top, with the application of $30 \mathrm{t} \mathrm{ha}^{-1}$, the organic carbon content increased $134.26 \%$ when compared to the control, which reflects positively on the cation exchange capacity (CEC), which is fundamental for the Latosol that has predominance of low activity clay.

In addition to the organic carbon, studies have shown that the application of biochar, when compared to the residue used in its manufacture, has a longer permanence in the soil due to its recalcitrant nature Steiner et al. (2008), which can reach hundreds of years (Cheng et al., 2008; Zimmerman, 2010). Long-term studies involving frequent applications of fresh biomass of cellulose waste in sandy soil did not verify the long-term accumulation of carbon in the soil (Curnoe et al., 2006). However, Van Zwieten et al. (2010) found that cellulose biochar significantly increased soil $\mathrm{C}$ content in the range of 0.5 to $1.0 \%$. In addition, biochar proved to be effective for carbon sequestration Vaccari et al. (2011), increasing soil fertility Wang et al. (2009) and improving the liming potential of acid soils (Yuan et al., 2011).

Although biochar promotes increased soil fertility, especially at the top, the availability of nutrients is temporary for plants, depending on the residence time of the biochar in this environment. It is known that over time, new additions of biochar continue to promote soil nutrient availability, leading to greater stabilization of organic matter and a subsequent reduction in nutrient release (Lehmann \& Rondon, 2006).

The cation exchange capacity of the soil increased as a function of the increasing doses of the biochar only at the top of the soil, whose highest calculated average corresponded to $6.76 \mathrm{cmol}_{\mathrm{c}} \mathrm{dm}^{-3}$ with the application of $30 \mathrm{t}$ $\mathrm{ha}^{-1}$ (Figure 1J). At the base of the column, the mean CEC corresponded to $6.02 \mathrm{cmolc} \mathrm{dm}^{-3}$. The CEC values differed statistically between the layers analyzed using the first three dosages $\left(0 ; 5\right.$ and $\left.10 \mathrm{tha}^{-1}\right)$ (Figure 1J). Also with respect to CEC, the basic cations were the main responsible for their increase in the top, while in the base, the potential acidity was determinant to maintain the same value of the CEC, regardless of the dose of biochar applied. These results suggest that the addition of biochar increases the ability of soils to retain nutrients, increasing the likelihood that they will be absorbed by the roots of plants, thereby reducing the leaching and transport of nutrients to surface or groundwater reservoirs. Andrade et al. (2015) also verified an increase in the $\mathrm{CEC}$ of the soil with the use of biochar doses.

Increasing doses of biochar applied to the soil significantly influenced the contents of the chemical elements analyzed in the leachate at the level of $p<0.01$, except for phosphorus (Table 2). 
Table 2. Summary of variance analysis related to $\mathrm{pH}$, electric conductivity (EC), calcium (Ca), magnesium (Mg), sodium $(\mathrm{Na})$, phosphorus $(\mathrm{P})$, potassium $(\mathrm{K})$ and bicarbonate $\left(\mathrm{HCO}_{3}\right)$ in the leachate as a function of the applied biochar doses

\begin{tabular}{|c|c|c|c|c|c|c|c|c|c|}
\hline \multirow{2}{*}{ Source of variation } & \multirow{2}{*}{ DF } & \multicolumn{8}{|c|}{ F-test } \\
\hline & & $\mathrm{pH}$ & $\mathrm{CE}$ & $\mathrm{Ca}$ & $\mathrm{Mg}$ & $\mathrm{Na}$ & $\mathrm{P}$ & $\mathrm{K}^{(1)}$ & $\mathrm{HCO}_{3}{ }^{(2)}$ \\
\hline Doses & 5 & $0.258^{* *}$ & $0.96^{* *}$ & $477.98^{* *}$ & $171.35^{* *}$ & $9873.13^{* *}$ & $0.278^{\mathrm{ns}}$ & $61.30^{* *}$ & $6.06^{* *}$ \\
\hline Linear & 1 & $1.092^{* *}$ & $4.71^{* *}$ & $2199.87^{* *}$ & $838.38^{* *}$ & $41329.63^{* *}$ & - & $299.49^{* *}$ & $27.7^{* *}$ \\
\hline Quadratic & 1 & $0.006^{\mathrm{ns}}$ & $0.03^{\mathrm{ns}}$ & $106.28^{*}$ & $8.82^{\text {ns }}$ & $851.68^{* *}$ & - & $0.77^{\text {ns }}$ & $0.32^{\mathrm{ns}}$ \\
\hline Deviation & 3 & $0.063^{\mathrm{ns}}$ & $0.02^{\mathrm{ns}}$ & $27.91^{\mathrm{ns}}$ & $3.18^{\text {ns }}$ & $2394.78^{* *}$ & - & $2.07^{\mathrm{ns}}$ & $0.74^{\mathrm{ns}}$ \\
\hline residue & 18 & 0.032 & 0.01 & 14.83 & 3.79 & 74.67 & 0.230 & 0.99 & 0.55 \\
\hline CV $(\%)$ & & 2.62 & 2.62 & 12.43 & 15.27 & 8.87 & 38.94 & 14.99 & 36.24 \\
\hline General Average & & 6.85 & 6.85 & 30.98 & 12.75 & 97.39 & 1.23 & 6.64 & 2.05 \\
\hline
\end{tabular}

Note. Significant at $5 \%\left(^{*}\right)$ and $1 \%(* *)$ of probability by F test, ns= not significant, DF $=$ Degree of freedom, $\mathrm{CV} \%=$ Coefficient of variation, ${ }^{(1)}$ and ${ }^{(2)}$ Data transformed to $\left(x^{0.277}-1\right) / 0.277$ and $\sqrt{x}$, respectively.

With the exception of $\mathrm{pH}$ and bicarbonate, the chemical parameters in the leachate increased significantly as a function of the doses of the biochar and, consequently, of the release of the chemical elements present in the biochar to the soil solution (Figure 2). This release increased the concentration of the elements in the soil solution (Figures 2C, 2D, 2E and 2F) and significantly, the electrical conductivity of the leachate (Figure 2B), whose average observed with the application of $30 \mathrm{t} \mathrm{ha}^{-1}$ of biochar was $473.58 \%$ higher than the mean of the control $\left(0 \mathrm{tha}^{-1}\right)$.

These results corroborate Yue et al. (2016) that after evaluating the effect of biochar (from sunflower straw, rice and bovine manure) on the leaching of ions in Aridisol, also verified increase in sodium, magnesium, calcium and potassium content not leached.

The decrease in the leachate $\mathrm{pH}$ to 6.6 with the use of the $30 \mathrm{t} \mathrm{ha}^{-1}$ biochar (Figure 2A) was probably caused by the removal of $\mathrm{Al}$ and the $\mathrm{H}$ from the sortive complex and leached to the soil solution by the basic cations of structure of the biochar. According to the higher mobility of $\mathrm{Al}$ and $\mathrm{H}$ in the leach column, their concentrations increased at the base (depth of 10-20 cm) when compared to the top (depth of 0-10 cm), regardless of the applied dose (Figure $1 \mathrm{H}$ ). This, probably, due to the cationic exchange of $\mathrm{Al}$ by the $\mathrm{Ca}$ and the $\mathrm{Mg}$ of the biochar, releasing $\mathrm{H}$ by the hydrolysis of $\mathrm{Al}$, thus reducing the $\mathrm{pH}$ of the effluent.

Calcium and sodium averages were adjusted to the second-order polynomial regression model whose maximum contents were overestimated at $42.07 \mathrm{mg} /$ leachate $\left(36.57 \mathrm{t} \mathrm{ha}^{-1}\right)$ and $165.59 \mathrm{mg} /$ leachate $\left(47.81 \mathrm{t} \mathrm{ha} \mathrm{h}^{-1}\right)$, respectively. As for magnesium and potassium, their content increased linearly as a function of the applied doses of biochar, reaching, at the highest dosage, averages of 20.74 and $172.04 \mathrm{mg}$ of $\mathrm{Mg}$ and $\mathrm{K}$, respectively, the latter two averages corresponding to the non-values transformed. In addition, the untransformed averages of bicarbonate presented a similar behavior to that observed for the $\mathrm{pH}$, that is, they decreased as a function of the applied doses, which was expected since the presence of this ion is associated to the alkalinity of the water (Figure 2).

Potassium and magnesium content increased linearly as a function of the applied doses of biochar (Figures 2C and 2E), reaching, at the highest dosage, averages of 172.04 and $20.74 \mathrm{mg}$ of $\mathrm{K}$ and $\mathrm{Mg}$, respectively, the latter two averages corresponding to the non-values transformed. Calcium and sodium averages were adjusted to the second order polynomial regression model (Figures $2 \mathrm{D}$ and $2 \mathrm{~F}$ ) whose maximum contents were overestimated at $42.07 \mathrm{mg} /$ leachate $\left(36.57 \mathrm{t} \mathrm{ha}^{-1}\right)$ and $165.59 \mathrm{mg} /$ leachate $\left(47.81 \mathrm{t} \mathrm{ha}^{-1}\right)$, respectively. In addition, the untransformed averages of bicarbonate presented a similar behavior to that observed for the $\mathrm{pH}$, that is, they decreased as a function of the applied doses, which was expected since the presence of this ion is associated to the alkalinity of the water (Figure $2 \mathrm{G}$ ).

The electrical conductivity of the leachate was also significantly influenced by the biochar, whose average observed with the dose of $30 \mathrm{t} \mathrm{ha}^{-1}$ of biochar was $473.58 \%$ higher in relation to the control $\left(0 \mathrm{t} \mathrm{ha}^{-1}\right)($ Figure $2 \mathrm{~B})$. This occurred because the application of the biochar increased the concentration of the nutrients in the solution, favoring the vertical displacement of the same with the descending flow of water.

Although the content of the analyzed nutrients increased according to the doses of biochar, the total amount of calcium, magnesium and potassium present in the leachate corresponded to only $1.81 ; 5.70$ and $0.93 \%$, respectively, provided by the $30 \mathrm{t} \mathrm{ha}^{-1}$ dose, after subtraction of the leachate amount from the control treatment. 
Therefore, the results obtained from this research suggest that even with leaching of the chemical elements, the application of biochar increases the ability of soils to retain these elements, thus reducing the risk of being leached and transported to underground reservoirs.
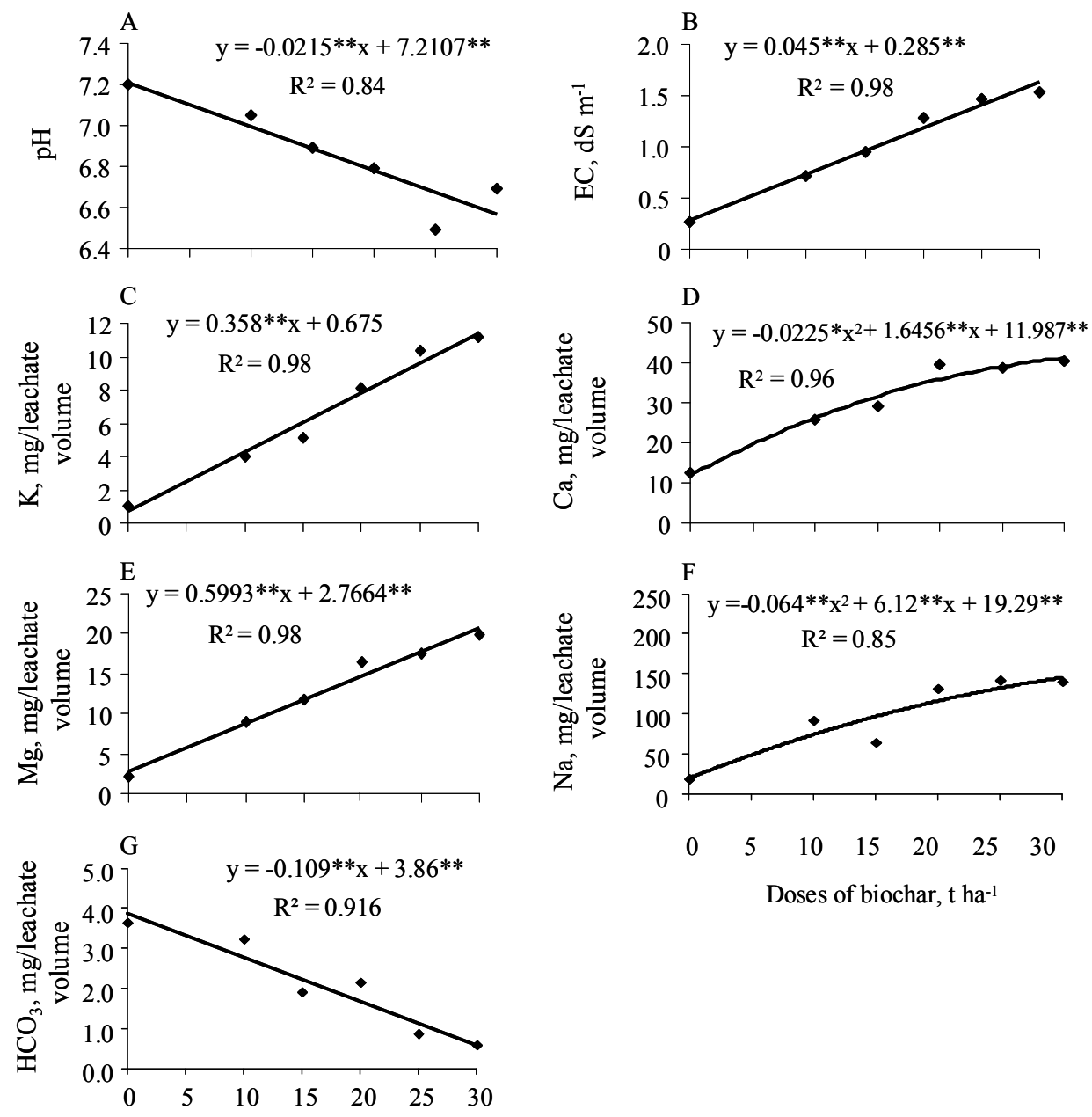

Doses of biochar, $\mathrm{t}$ ha-1

Figure 2. Electrical conductivity, $\mathrm{pH}$ and calcium, magnesium, potassium, phosphorus and carbonate content in leachate due to the application of different doses of biochar

\section{Conclusion}

Biochar was an effective liming agent neutralizing solution $\mathrm{pH}$ and reducing exchangeable acidity values.

Biochar caused significant soil fertility improvements.

Leachates contained increasing electrical conductivity, potassium, sodium, calcium and magnesium, however the concentration of these elements were small in relation to the doses of biochar applied to the soil.

\section{References}

Andrade, C. A., Bibar, M. P. S., Coscione, A. R., Pires, A. M. M., \& Soares, A. G. (2015). Mineralização e efeitos de biocarvão de cama de frango sobre a capacidade de troca catiônica do solo. Pesquisa Agropecuária Brasileira, 50(5), 407-416. https://doi.org/10.1590/S0100-204X2015000500008

APHA (American Public Health Association). (2012). Phosphorous. In L. S. Clesceri, A. E. Greenberg, A. D. Eaton (Eds.), Standard Methods for the Examination of Water and Wasterwater (22nd ed.). Washington: American Public Health Association. 
Brasil. (2014). Ministério da Agricultura, Pecuária e Abastecimento. Manual de métodos analíticos oficiais para fertilizantes minerais, orgânicos, organominerais e corretivos (p. 220). Brasília: Ministério da Agricultura, Pecuária e Abastecimento; Secretaria de Defesa Agropecuária; Coordenação-Geral de Apoio Laboratorial; Murilo Carlos Muniz Veras.

Chaves, L. H. G., Lima, W. B., Chaves, I. B., Buriti, J. S., Fook, M. V. L., \& Souza, J. W. L. (2018). Effect of poultry litter biochar on Ultisol physical properties. African Journal of Agricultural Research, 13(9), 412-418. https://doi.org/10.5897/AJAR2018.12991

Cheng, C. H., Lehmann, J., \& Engelhard, M. H. (2008). Natural oxidation of black carbon in soils: Changes in molecular form and surface charge along a climosequence. Geochimica et Cosmochimica Acta, 72(6), 1598-1610. https://doi.org/10.1016/j.gca.2008.01.010

Curnoe, W. E., Irving, D. C., Dow, C. B., Velema, G., \& Une, A. (2006). Effect of spring application of a paper mill soil conditioner on corn yield. Agronomy Journal, 98, 423-429. https://doi.org/10.2134/agronj 2005.0041

EMBRAPA (Empresa Brasileira de Pesquisa Agropecuária). (2011). Manual e métodos de análise de solo. Rio de Janeiro: Embrapa Solos.

EMBRAPA (Empresa Brasileira de Pesquisa Agropecuária). (2013). Centro Nacional de Pesquisa de solos. Sistema brasileiro de classificação de solos (3rd ed., p. 353). Rio de Janeiro: EMBRAPA-SPI.

Ferreira, D. F. (2011). Sisvar: A computer statistical analysis system. Ciência e Agrotecnologia, 35(6), 1039-1042. https://doi.org/10.1590/S1413-70542011000600001

Furtado, G. F., \& Chaves, L. H. G. (2018). Growth rates and sunflower production in function of fertilization with biochar and NPK. Journal of Agricultural Science, 10(2), 260-270. https://doi.org/10.5539/ jas.v10n2p260

Knicker, H. (2007). Como o fogo afeta a natureza e a estabilidade do nitrogênio orgânico do solo e do carbono? Uma revisão. Biogeoquímica, 85, 91-118.

Laird, D., Fleming, P., Wang, B., Horton, R., \& Karlen, D. (2010). Biochar impact on nutrient leaching from a Midwestern agricultural soil. Geoderma, 158, 436-442. https://doi.org/10.1016/j.geoderma.2010.05.012

Lehmann, J., \& Rondon, M. (2006). Bio-char soil management in highly weathered soils in the humid tropics. In N. Uphoff, A. S. Ball, E. Fernandes, H. Herren, O. Husson, M. Laing, ... J. Thies (Eds.), Biological approaches to sustainable soil systems (pp. 517-530). CRC Press Taylor \& Francis Group, Boca Raton.

Lima, W. B., Fernandes, J. D., Chaves, L. H. G., Tito, G. A., \& Chaves, I. B. (2017). Adsorption of zinc in ultisol and entisol amended with poultry litter biochar. World Applied Sciences Journal, 35(1), 142-150. https://doi.org/10.5829/idosi.wasj.2017.142.150

Major, J., Rondon, M., Molina, D., Riha, S. J., \& Lehmann, J. (2010). Maize Yield and nutrition during 4 years after biochar application to a Colombian savanna oxisol. Plant and Soil, 333(1-2), 117-128. https://doi.org/ 10.1007/s11104-010-0327-0

Martinez, M. J., Espana, J. C., \& Diaz, J. D. J. (2017). Effect of Eucalyptus globullus biochar addition on the availability of phosphorus in acidic soil. Agronomía Colombiana, 35(1), 75-81. https://doi.org/10.15446/ agron.colomb.v35n1.58671

Mendes, J. S., Chaves, L. H. G., Chaves, I. B., Silva, F. A. S., \& Fernandes, J. D. (2015a). Using Poultry litter biochar and rock dust MB-4 on release available phosphorus to soils. Agricultural Sciences, 6, 1367-1374, https://doi.org/10.4236/as.2015.611131

Mendes, J. S., Chaves, L. H. G., Fernandes, J. D., \& Chaves, I. B. (2015b). Using MB-4 rock powder, poultry litter biochar, silicate and calcium carbonate to amend different soil types. Australian Journal of Crop Science, 9(10), 987-995.

Mendes, L. B., Tinoco, I. F. F., Souza, C. F., \& Saraz, J. A. O. (2012). O ciclo do nitrogênio na criação de frangos de corte e suas perdas na forma de amônia volátil: Uma revisão. Pubvet, 6(20), 1381-1386.

Mueller, S., Wamser, A. F., Suzuki, A., \& Becker, W. F. (2013). Produtividade de tomate sob adubação orgânica e complementação com adubos minerais. Horticultura Brasileira, 31(1), 86-92.

Novak, J. M., Busscher, W. J., Laird, D. L., Ahmedna, M., Watts, D. W., \& Niandou, M. A. S. (2009). Impact of biochar amendment on fertility of a southeastern Coastal. Soil Science, 174, 105-112. 
Novak, J. M., Lima, I., Xing, B., Gaskin, J. W., Steiner, C., Das, K., ... Busscher, W. J. (2009). Characterization of designer biochar produced at different temperatures and their effects on a loamy sand. Annals of Environmental Science, 3, 195-206.

Oviedo-Rondon, E. O. (2008). Technologies to mitigate the environmental impact of broiler production. Revista Brasileira de Zootecnia, 37, 239-252. https://doi.org/10.1590/S1516-35982008001300028

Patterson, P. H., Lorenz, E. S., Weaver, W. D., \& Schwartz, J. H. (1998). Litter production and nutrients from commercial broiler chickens. The Jounal of Applied Poultty Research, 7(3), 247-252.

Silva, I. C. B., Basílio, J. J. N., Fernandes, L. A., Colen, F., Sampaio, R. A., \& Frazão, L. A. (2017). Biochar from different residues on soil properties and common bean production. Scientia Agricola, 74(5), 378-382. https://doi.org/10.1590/1678-992x-2016-0242

Sparks, D. L. (2003). Environmental soil chemistry. Academic Press, San Diego, CA, USA.

Steiner, C., Glaser, B., Teixeira, W. G., Lehmann, J., Blum, W. E. H., \& Zech, W. (2008). Nitrogen retention and plant uptake on a highly weathered central Amazonian Ferralsol amended with compost and charcoal. Journal of Plant Nutrition and Soil Science, 171, 893-899. https://doi.org/10.1002/jpln.200625199

USDA (United States Department of Agriculture). (2010). Produtividade mundial avícola. Retrieved from http://www.usda.gov

Vaccari, F. P., Baronti, S., Lugata, E., Genesio, L., Castaldi, S., Fornasier, F., \& Miglietta, F. (2011). Biochar as a strategy to sequester carbon and increase yield in durum wheat. European Journal of Agronomy, 34, 231-238. https://doi.org/10.1016/j.eja.2011.01.006

Van Zwieten, L., Kimber, S., Morris, S., Chan, K. Y., Downie, A., Rust, J., ... Cowie, A. (2010). Effects of biochar from slow pyrolysis of papermill waste on agronomic performance and soil fertility. Plant and Soil, 327, 235-246. https://doi.org/10.1007/s11104-009-0050-x

Wang, N., Li, J. Y., \& Xu, R. K. (2009). Use of various agricultural by-products to study the pH effects in an acid tea garden soil. Soil Use Management, 25, 128-132. https://doi.org/10.1111/j.1475-2743.2009.00203.x

Yuan, J. H., \& Xu, R. K. (2012). Effects of biochars generated from crop residues on chemical properties of acid soils from tropical and subtropical China. Soil Research, 50, 570-78. https://doi.org/10.1071/SR12118

Yuan, J. H., Xu, R. K., Wang, N., \& Li, J. Y. (2011). Amendment of acid soils with crop residues and biochars. Pedosphere, 21, 302-308. https://doi.org/10.1016/S1002-0160(11)60130-6

Yue, Y., Guo, W. N., Lin, Q. M., Li, G. T., \& Zhao, X. R. (2016). Improving salt leaching in a simulated saline soil column by three biochars derived from rice straw (Oryza sativa L.), sunflower straw (Helianthus annuus), and cow manure. Journal of Soil and Water Conservation, 71(6), 467-475. https://doi.org/10.2489/ jswc.71.6.467

Zimmerman, A. R. (2010). Abiotic and Microbial Oxidation of Laboratory-Produced Black Carbon (Biochar). Environmental Science \& Technology, 44, 1295-1301. https://doi.org/10.1021/es903140c

\section{Copyrights}

Copyright for this article is retained by the author (s), with first publication rights granted to the journal.

This is an open-access article distributed under the terms and conditions of the Creative Commons Attribution license (http://creativecommons.org/licenses/by/4.0/). 